\title{
Examining Deterrent Concept of Capital Punishment in Indonesian Penal System
}

\author{
Manotar Tampubolon \\ Faculty of Law, Christian University of Indonesia, Indonesia
}

\begin{abstract}
This article examines the effectivity of the death penalty in Indonesia ancient and modern law applies to some categories of crimes. Earlier proponents agree that the death penalty should be useful as often as possible to prevent future crimes and provide a sense of justice and moral order. On the opposite side, abolitionist agrees that the death penalty does not address future murders. Execution is brutalization and human sacrifice without consistent or reliable evidence that executions de jure availability had a deterrent effect on homicides - capital punishment as undeniably cruel, inhuman, and degrading. The death penalty does not have an era effect on criminals; imprisonment is more significant as a deterrent against the perpetrator. This study uses a historical-legal perspective to assess the strength and weaknesses of the concept. The result shows, however, there is no significant effect of the death penalty on crimes in Indonesia.
\end{abstract}

Keywords: death penalty; deterrent; premeditated murder; narcotics; terrorism 